\title{
Asymmetries in the Union Wage Premium in Ghana
}

\author{
Niels-Hugo Blunch and Dorte Verner
}

\begin{abstract}
There is little evidence on the size of the union wage premium in developing economies. The article uses a matched employer-employee data set for Ghana and adopts a quantile regression approach that allows the effects of unionization to vary across the conditional wage distribution. It is shown that if there are intrafirm differences in unionization, there does appear to be a premium among poorer paid workers in the formal sector. Although this cannot be given a causal interpretation, it suggests important issues about how unions may affect one part of the labor market.
\end{abstract}

I did not begin my research on Ghanaian trade unions with the idea that organized labor could rescue this small, developing West African state from its economic difficulties. But neither did I have the pre-conceived notion, today popular in some quarters, that unions are irrelevant to the struggles of Third World peoples to maximize their own freedom.

-Paul S. Gray (1981)

Experience in developed economies suggests that unions may be a mechanism for providing a positive work environment by reducing labor turnover and wage negotiation costs and promoting worker training, increased benefits, and higher productivity (Standing 1992). Unions have also been found to reduce wage inequality and wage discrimination (Chaykowski and Slotsve 2002; Freeman 1980; Panagides and Patrinos 1994; Standing 1992). Much less is known about unions in developing economies, particularly in Sub-Saharan African countries. ${ }^{1}$ Such analysis seems especially warranted for these countries as a basis for policy proposals. Formal sector jobs are scarce and wages are generally low, leading both to poverty and-because of low tax revenues-low levels of goods and services from the public sector.

To shed some light on these issues in developing economies, this article analyzes wage determinants in Ghanaian manufacturing industries, focusing on

Niels-Hugo Blunch is a consultant in the Social Protection Unit of the Human Development Network at the World Bank and a Ph.D. candidate at The George Washington University; his e-mail address is nblunch@worldbank.org. Dorte Verner is a senior country economist in the Social Development Family of the Latin America and Caribbean Region at the World Bank; her e-mail address is dverner@worldbank.org. The authors thank François Bourguignon, Sudharshan Canagarajah, Donald Parsons, and participants at a seminar at the Centre for Labour Market and Social Research, Aarhus, Denmark, for helpful comments and suggestions. Comments and suggestions from three anonymous referees and a journal review board member helped greatly improve this article.

1. See, however, Kristensen and Verner (1999), Rama (2000), and Schultz and Mwabu (1998).

THE WORLD BANK ECONOMIC REVIEW, VOL. 18, NO. 2,

(C) The International Bank for Reconstruction and Development / THE WORLD BANK 2004; all rights reserved. doi:10.1093/wber/lhh040

$18: 237-252$ 
the association of union membership and wages and the possible asymmetries in this association across the conditional wage distribution. Ghana is an ideal candidate for such analysis because of its long history of active labor unions. ${ }^{2}$

\section{Hypotheses}

A union premium could arise through three possible channels. First is the direct effect through individual union membership. This is the standard union premium, well known from the empirical literature on the union relative wage effect beginning with Lewis (1963). ${ }^{3}$ Second, because this does not take into account possible spillovers to nonunion workers, the analysis here allows unionism to potentially affect all workers through an industry-level union density variable. Third, there might be an additional union effect arising from training (Booth and Chatterji 1998; Booth and others 1999), because unions may promote training more than management does. For example, unions can have a longer time horizon than management, which may focus on maximizing profits and stock values in the short term, or unions may counterbalance the firm's ex post monopsonistic power in wage determination. Thus where unions are active there may be increased recognition of the value of training, so that trained workers receive a wage premium. ${ }^{4}$ (Booth and Chatterji 1998 and Booth and others 1999 develop theoretical models in which a key prediction is that union workers receive more training and higher returns to training than do nonunion workers.)

The hypothesis here is that union effects are more likely at the lower part of the wage distribution, because unions are generally seen as (and generally perceive themselves as) proponents of workers' rights and wages for the poorer or less skilled segment of the workforce. This view is also in line with previous research, which generally finds that unions reduce wage inequality and wage discrimination. Chamberlain (1994) finds distinct asymmetries in the union premia in U.S. manufacturing, which is 28 percent at the bottom decile but declines monotonically to 0.3 percent at the top decile. This contrasts with an ordinary least squares (oLs) estimate of the mean union premium of 15.8 percent, driven primarily by the bottom decile of the conditional distribution (for Ghana, the result is still more

2. Unionism is low or even absent in many countries of Sub-Saharan Africa because of the economic dominance of smallholder agriculture and the historically prohibition against independent trade unions in many countries. Ghana, however, has a long tradition of labor unions, originating with the many guilds and artisan associations in the early nineteenth century (Gray 1981). The potential synergies between labor organizations and government were anticipated early, even before Ghana's independence from British rule in 1957: "As early as 1930, Lord Passfield (Sidney Webb) had noted in a dispatch that regulation of wage laborer organizations was of importance, and that colonial governments should act to facilitate the passage of unions into constitutional channels" (Gray 1981, p. 14).

3. To avoid a causal interpretation, we use the term union wage premium rather than union relative wage effect, which has previously been widely used in the literature but unfortunately might suggest a causal relationship.

4. Alternatively, unions may enable trained workers to extract the rents created by workers. 
striking, with the mean union premium disappearing altogether). More recently, Card (1996) finds similar results for the United States and Chaykowski and Slotsve (2002) for Canada.

Thus, although there is some evidence of asymmetry in the union wage premium for developed countries, such asymmetry may be particularly relevant for developing economies, where the high costs of monitoring may prevent effective monitoring of adherence to minimum wage legislation. Unions in developed areas may bargain more on behalf of workers from the middle part of the wage distribution because minimum wage legislation is generally adhered to. Thus for developing and developed economies alike, the upper part of the wage distribution would not be expected to exhibit a positive and statistically significant association between wages and individual union membership.

Analyzing the impact of unions across the entire wage distribution is thus important for at least two reasons (Chaykowski and Slotsve 2002). First, it may shed light on whether unions have an impact on particular socioeconomic groups in the labor market, enriching the social and economic view of unions, including whether unionism should be reinforced or retrenched. Second, such analyses provide insight into which workers benefit most from unions and, therefore, help identify which groups unions may most successfully appeal.

Before getting on with the analysis, some words of caution about interpreting the results are in order. First, because matched employer-employee panel data sets for Sub-Saharan Africa are rare, the empirical analysis is limited to crosssection data-as is the case for most wage equation studies for Sub-Saharan Africa. That means that individual effects, which might otherwise overcome the possible selection of workers into unions (on unobservables such as type or ability; see Card 1996 for a study for the United States using panel data), cannot be isolated. Second, to account for selection into unions using cross-section data requires an exclusion restriction (or instrument). This is also not feasible for the present analysis because there are no readily available variables that affect selection into unions but do not affect wages directly. Controlling for firm size should somewhat mitigate the biases arising from the nonrandom placement of unions (at the aggregate level) into sectors or industries, ${ }^{5}$ but the possibility of selection of workers into unions at the individual level based on unobservables (ability, motivation) remains. The results should therefore be seen as suggestive rather than as explicitly causal. ${ }^{6}$

5. Previous studies of the association of union membership and wages have not always been able to control for firm size. Schultz and Mwabu (1998), for example, analyzing the association of individual union membership and wages and unemployment in South Africa using a quantile regression framework, note the importance of this variable with respect to the nonrandom placement of unions but are unable to include the variable in their analyses because it is not part of their data set.

6. It may be that unions are simply more active in higher-wage sectors. Again, because high-wage sectors are also typically found to be those with larger firms, controlling for firm size should at least mitigate some of this bias. 


\section{Data and Descriptive Analysis}

The data are from the Regional Program on Enterprise Development survey for Ghana, organized by the World Bank and funded by the British Overseas Development Administration and conducted by the Centre for the Study of African Economies at the University of Oxford and the University of Ghana at Legon in $1994 .^{7}$ Although the survey yields information on firms and workers in 180 manufacturing firms, missing observations for one or more variables resulted in an effective estimation sample of 683 workers in 108 firms.

The main variables applied in this study include a "core" of $(\log )$ monthly wages (including allowances); the standard human capital variables of age and age squared (to capture potential general experience), tenure in the firm and tenure squared (to capture potential specific experience), highest level of education completed, training variables (whether a worker has received training within the firm), and occupational control variables and firm-level control variables, most notably firm size by number of employees (the appendix lists the variables and their definitions). ${ }^{8}$

The possible existence of a union wage premium may be determined in various ways. The first thing to consider is the channel through which unions may affect wages: Is there an individual, direct effect through union membership, or is there an indirect effect through the degree of unionization at an establishment or in an industry as a reflection of the bargaining power of a union within a firm or industry, thus allowing for spillovers to nonunion workers? This is examined as an empirical question, through a dummy variable for individual union membership and an industry-level union density variable. The aggregate union wage premium (spillover mechanism) is modeled using the degree of unionization at the industry rather than at the firm level largely because collective bargaining in Ghana occurs mostly at the more aggregated industry level (Gray 1981). This approach further ensures that collinearity is not likely to be a serious problem, because these two union variables are only weakly correlated (a simple correlation of 0.08 ), whereas the individual union membership and firm union density variables have a simple correlation of 0.76 , so including both of these in the same regression could result in substantial collinearity problems. ${ }^{9}$

7. Surveys were conducted in 1992, 1993, and 1994. Although the surveys have a panel structure for collecting firm-level data, the data on workers were collected as independent cross-sections. The analysis therefore includes only the most recent of the three surveys, treating the data as cross-sectional for both firms and workers.

8. Larger establishments tend to pay higher wages than smaller establishments, controlling for other factors (Schaffner 1998; Velenchik 1997). Not controlling for this, therefore, could lead to substantial omitted-variable bias.

9. Maloney and Ribeiro (1999) include the union density variable at the firm level, arguing that this is a proxy for the bargaining power of the union over the firm's rents. However, the high correlation between this variable and the dummy variable for individual union membership in the Ghana sample means that inclusion of both would likely yield problems with multicollinearity, and so it does not appear valid to simultaneously allow the two different channels of a union relative effect (individual and aggregate spillover) proposed here. 
There may still be an endogeneity issue related to the use of the variable of individual union membership, however. What is needed is a good instrument that may help explain individual union membership without also explaining wages. Because the data set lacks such a variable, the analysis follows Schultz and Mwabu (1998) in arguing that it is beyond the scope of the data to endogenize union membership, including explaining who gets a union job and who does not, and to explain the extent to which unions enhance the productivity of workers with the same observable characteristics. As a result, any estimated union wage premium may overstate or understate the true union wage premium.

Because the estimated coefficient picks up the effect from the omitted variable as well, the omission of any variable influencing wage determination that is positively correlated with the union variable will cause the estimated coefficient on the union variable to be upwardly biased, whereas the omission of a negatively correlated variable will cause the estimated coefficient to be downwardly biased. For example, it may be conjectured that nonunion jobs are typically found in smaller establishments or industries because it takes a certain size for an establishment or industry to become interesting for a union in terms of potential members. Hence, failure to control for firm size may cause bias in the union premium. However, the present data set permits incorporating firm size as an explanatory variable, which likely decreases such bias considerably. Furthermore, it may be conjectured that firms that have become unionized respond to unionization by carefully vetting prospective new workers so as to employ even higher quality workers than before because of increased wage demands. Because "quality" or "ability" is unmeasurable, omitted variable bias is again possible in the union wage premium estimates. The same applies to the labor turnover argument: If unions reduce labor turnover, and this effect cannot be directly observed and included as an explanatory variable, the result is once again omitted variable bias in the union premium estimate.

With a panel data set one solution is to extract the individual fixed effect of the data, thus mitigating the potential bias (see, for example, Card 1996). But with a cross-section data set, as in this case, unionism has to be modeled based on individual union membership (and possibly a variable of union density at the firm or industry level, constructed from this).

Even though the data do not allow for fully endogenizing union membership, it is possible to shed some light on whether the endogeneity of individual union membership will pose severe problems for the subsequent analyses by doing some descriptive work. Data on individual and firm characteristics across union membership reveal that union workers earn higher wages than nonunion workers, not controlling for other characteristics (table 1). However, union workers (and their firms) are different from nonunion workers (and their firms) in several ways (although not always statistically significantly so). They are better educated, older, and more experienced (within the firm). They are also more likely to have a permanent contract. At 127 employees, the average firm size of unionized workers is much larger than that of nonunionized workers, at 
TABLE 1. Worker and Firm Characteristics across Individual Union

Membership

\begin{tabular}{|c|c|c|c|c|c|c|}
\hline \multirow[b]{2}{*}{ Variable } & \multicolumn{2}{|c|}{ Nonunion worker } & \multicolumn{2}{|c|}{ Union member } & \multirow[b]{2}{*}{ Difference } & \multirow[b]{2}{*}{$t$-Statistic } \\
\hline & Mean & SD & Mean & SD & & \\
\hline Log(wages) & 10.522 & 0.077 & 10.752 & 0.054 & $0.230 * * *$ & 2.65 \\
\hline Age & 34.1 & 0.870 & 36.1 & 0.949 & 2.0 & 1.58 \\
\hline Gender & 0.204 & 0.032 & 0.153 & 0.031 & -0.050 & 1.21 \\
\hline None & 0.094 & 0.021 & 0.094 & 0.030 & 0.001 & 0.01 \\
\hline Primary & 0.037 & 0.012 & 0.015 & 0.008 & -0.023 & 1.53 \\
\hline Middle & 0.509 & 0.032 & 0.446 & 0.045 & -0.064 & 1.15 \\
\hline Secondary & 0.123 & 0.024 & 0.124 & 0.030 & 0.001 & 0.03 \\
\hline Vocational & 0.102 & 0.017 & 0.183 & 0.032 & $0.081 * *$ & 2.29 \\
\hline Polytechnic & 0.073 & 0.016 & 0.124 & 0.033 & 0.051 & 1.44 \\
\hline Professional & 0.042 & 0.012 & 0.015 & 0.008 & $-0.027^{*}$ & 1.98 \\
\hline University & 0.021 & 0.007 & 0.000 & 0.000 & $-0.021 * * *$ & 2.99 \\
\hline Production & 0.443 & 0.040 & 0.376 & 0.039 & -0.067 & 1.22 \\
\hline Administration & 0.104 & 0.024 & 0.193 & 0.030 & $0.089 \div *$ & 2.44 \\
\hline Commercial & 0.062 & 0.014 & 0.079 & 0.020 & 0.017 & 0.70 \\
\hline Professional & 0.046 & 0.012 & 0.025 & 0.015 & -0.021 & 1.06 \\
\hline Support staff & 0.098 & 0.030 & 0.178 & 0.036 & $0.081 *$ & 1.86 \\
\hline Manager & 0.127 & 0.017 & 0.099 & 0.026 & -0.028 & 0.93 \\
\hline Experience (years) & 5.9 & 0.562 & 8.3 & 0.926 & $2.4^{* *}$ & 2.27 \\
\hline Permanent contract & 0.969 & 0.012 & 1.000 & 0.000 & $0.031 \% *$ & 2.50 \\
\hline Received training in firm & 0.320 & 0.045 & 0.282 & 0.049 & -0.038 & 0.59 \\
\hline Accra & 0.611 & 0.056 & 0.629 & 0.088 & 0.017 & 0.19 \\
\hline Number of employees in firm & 64.8 & 12.072 & 126.7 & 27.601 & $61.8 * *$ & 2.21 \\
\hline
\end{tabular}

*Significant at the 10 percent level.

* Significant at the 5 percent level.

$* *$ Significant at the 1 percent level.

Note: Number of observations in the full sample $=683$. The clustering of workers within firms is taken into account in the calculation of SDs and $t$-statistics for $\mathrm{H}_{0}$ : Difference $=0$.

Source: Regional Program on Enterprise Development for Ghana (Wave III 1994).

65 employees. Firms of unionized workers are also more likely to be located in Accra, the capital.

That firm size is an important correlate of individual union membership is reassuring, because including this variable in subsequent analyses is likely to take care of many of the concerns with nonrandom placement of unions, at least at the aggregate level. However, selection is still possible and even probable at the individual level, where workers may select into unions based on preferences or latent personal characteristics or be chosen by employees based on latent personal characteristics, all of which are unobserved by the researcher. Again, although the data prevent a detailed analysis of individual determinants of union membership, the finding from the previous descriptive analysis that union workers (and their firms) are quite different from nonunion workers (and their firms) on observable characteristics suggests the likelihood of differences 
on unobservable characteristics such as ability and motivation as well. Yet additional calculations reveal that union membership is fairly evenly distributed across occupations and industries. For example, a production worker is only slightly more likely to be member of a union than a manager (26.3 and 24.7 percent). ${ }^{10}$

Because 98 percent of the sample has a permanent contract (table A-1), including that as an explanatory variable may appear fruitless because of the low variation. However, there is the possibility of an indirect effect from training. Employers would be more inclined to invest in training for employees who are likely to stay with the firm for some time, so the quantity or quality of training may be different for workers with a permanent contract. The variable for contract status is thus interacted with training. Because only about 30 percent of the sample both has a permanent contract and received training, this is likely to have some explanatory power because of its higher variation.

In sum, because the data are unsuitable for making explicit causal inferences about the effect of unions on wages, the analysis explores only the association between union membership and wages, keeping in mind the differing characteristics of union workers (and firms) and nonunion workers (and firms) and the possible nonrandom placement of unions into high-wage sectors.

\section{Methodology}

The theoretical framework for the analysis is standard human capital theory. An individual builds up knowledge and skills through education and experience (Becker 1964; Mincer 1974). Formally, the economic model is derived from the theory of individual demand for schooling, which views education as an investment in human capital (Becker 1964). In the traditional human capital literature, wages are determined by education and other individual characteristics. Because the Ghanaian data set allows inclusion of union- and firm-level variables, the standard Mincerian wage function is augmented with union- and firm-level characteristics

$$
W_{i}=W\left(I_{i}, F_{i}, U_{i}\right),
$$

where $W$, the wages of individual $i$, is the dependent variable; $I$ is a vector of individual characteristics (such as age and age squared proxying general experience; tenure in the firm, capturing firm-specific experience; the level of education; and gender); $F$ is a vector of characteristics for the firm of individual $i$, including the size of the firm (measured by the number of employees) and geographical location; and $U$ is a vector of variables capturing the possible

10. The industry-level union densities are 19.8 for wood, 25.7 for food, 32.1 for textiles, and 33.1 for metal. 
union wage premium for individual $i$, as measured by individual union membership or the union density of the industry or firm (as discussed in the previous section).

Lewis (1963) defines the union-nonunion wage differential (referred to here as the union wage premium) as ${ }^{11}$

$$
r_{i}=\left(W_{i}^{u}-W_{i}^{n}\right) / W_{i}^{n} .
$$

The possible existence and magnitude of the wage differential depend on the extent to which the union affects the wages of union workers relative to the wages of nonunion workers. At one extreme the union may, through its bargaining power, merely extract and subsequently share the existing rents of the firm (in the form of profits) with its members. At the other extreme, the union may generate rents through its potential adverse effects on labor turnover and the costs of wage negotiations between management and workers. In reality, a combination of these two effects would be expected.

The theory is silent on the precise empirical implementation of this notion of a union wage premium, which is left to individual researchers. This study uses quantile regression analysis. It enables simultaneously estimating the marginal effects for different quantiles (where the quantile of interest may be chosen arbitrarily) of the dependent variable, thus exploring the entire conditional distribution.

The main advantage here is the semi-parametric nature of the approach, which relaxes the restrictions on the parameters being constant across the entire conditional distribution of the dependent variable. A priori, the union wage premium might be expected to differ across the conditional wage distribution. For example, unions may be bargaining mainly on behalf of workers at the lower end of the wage distribution. As noted, this is especially likely in developing economies, where minimum wage legislation may not always be strictly adhered to because of the high costs of monitoring. Furthermore, it seems likely that the returns to education and tenure, for example, would differ across the wage distribution. For example, education might be thought to be a more important determinant at higher quantiles than at lower quantiles. ${ }^{12}$

The method has other virtues, as well. Allowing the parameter estimates for the marginal effects of the explanatory variables to differ across quantiles of the dependent variable achieves greater robustness to potential heteroscedasticity. This contrasts with OLS regression analysis, which requires homoscedasticity

11. The union-nonunion wage differential or union wage premium—which is the focus here-is only one aspect of the economics of unions. For an excellent recent survey of the economics of unions in a broader context, see Booth (1995). See also Lewis (1963, 1986), Freeman and Medoff (1984), and Pencavel (1995).

12. This turns out to be the case. An extended version of this article with the full set of results is available online at www.niels-hugo.dk. 
(indeed, in most of the empirical literature, the presence of homoscedasticity is merely a maintained hypothesis). Additionally, when the error terms are nonnormal, for instance, quantile regression estimators may be more efficient than least squares estimators. Furthermore, because the quantile regression objective function is a weighted sum of absolute deviations, it yields a robust measure of location. As a consequence, the estimated coefficient vector is not as sensitive to extreme observations of the dependent variable.

The method, developed by Koenker and Basset (1978), can be formulated as

$$
Y_{i}=X_{i} \beta_{\theta}+u_{\theta i}=\operatorname{Quant}_{\theta}\left(Y_{i} \mid X_{i}\right)=X_{i} \beta_{\theta}
$$

where Quant $_{\theta}\left(Y_{i} \mid X_{i}\right)$ denotes the $\theta$ th conditional quantile of $Y$ given $\mathrm{X}$ for individual $i$.

In general, the $\theta$ th sample quantile $(0<\theta<1)$ of $Y$ solves

$$
\min _{\beta}=\frac{1}{n}\left\{\sum_{i: Y_{i} \geq X_{i}^{\prime} \beta} \theta\left|Y_{i}-X_{i}^{\prime} \beta\right|+\sum_{i: Y_{i}<X_{i}^{\prime} \beta}(1-\theta)\left|Y_{i}-X_{i}^{\prime} \beta\right|\right\}
$$

Rogers (1992) suggests that previous methods used for calculating standard errors (often done following Koenker and Basset 1982) are inappropriate in the presence of heteroscedastic errors. The standard errors are therefore bootstrapped along the lines of Gould (1992, 1997). Additionally, the estimator incorporates the sample design-that is, it takes into account that workers are clustered within firms. If clustering is not taken into account, the resulting standard errors are potentially seriously misleading, especially for finite sample standard errors like the bootstrap.

\section{Econometric Analysis}

Because the focus here is the union wage premium, the other results are not discussed in detail. ${ }^{13}$ Although the other results are largely consistent with the findings in the empirical human capital literature (e.g., significant and positive returns to education ${ }^{14}$ and positive premiums to employees of larger establishments ${ }^{15}$ ), the other variables are considered only as controls here to generate valid estimates for the union wage premium (the appendix lists the variables and their definitions).

13. An extended version of this article with the full set of results is available online at www.nielshugo.dk.

14. See Psacharopoulos $(1985,1994)$ for a summary of the results of more than 60 studies on returns to education.

15. For example, Schaffner (1998) and Velenchik (1997) both find evidence that larger establishments pay higher wages, controlling for other (individual and firm) characteristics. 
Estimation is at the level of individual workers, and firm-level data are then matched to these workers. Three main models are estimated. The core model is a stripped down version of the other two, serving as a benchmark of comparison with the richer models. It allows for a union premium coming only through individual membership (this is the traditional union wage premium model widely pursued in the literature). Because of endogeneity concerns with respect to workers' training, this model also excludes the training variable (and its interactions). An extended intermediate model includes training variables, and the full model also includes the industry unionization density for the four industries: food, wood, metal, and textiles and an interaction term for union density and training (table 2 ). ${ }^{16}$ The full specification model therefore simultaneously allows for the union wage premium coming through two distinct channels: individual union membership and, to allow for a possible spillover effect to nonunion workers, industry union density. In addition to these three main models, the first model is estimated without the firm size variable to evaluate its importance for the union premium and to help explain the seeming discrepancy of the results here with those of Schultz and Mwabu (1998).

For the quantile regressions, the direct effect from union membership of the individual is positive and significant only for the bottom 10 percent of the conditional wage distribution, consistent with the conjecture that unions are the voice mainly of workers at the lower end of the wage distribution. The estimated union wage premium for the bottom decile is 41.3 percent $(\exp [0.346]-1)$ for the core model, 18.1 percent $(\exp [0.166]-1)$ for the intermediate model, and 16.9 percent $(\exp [0.156]-1)$ for the full specification model. These are lower than estimates for South Africa reported by Schultz and Mwabu (1998), who find union premiums at the bottom deciles of 145 percent for African males and 21 percent for white males.

In addition to the direct effect from individual union membership, there is an extra union membership effect from training, a finding in line with Booth and Chatterji (1998) and Booth and others (1999). The limitations of our data set prevent any causal interpretation of this result, which can be interpreted only as an association between unions and increased returns to training (from the worker's perspective). Alternatively, the correlation in the data could be capturing something about the larger differences in wages between trained and untrained workers in the relatively higher rent industries to which unions are drawn.

The union density of the industry does not influence wages directly, indicating the lack of a direct spillover effect to nonunion workers. There does seem to be an indirect spillover effect, however, coming through training. When the

16. This is also why industry dummy variables are not included, because they would be perfectly collinear with the industry unionization density variable. 
Table 2. Union Wage Premium Estimates

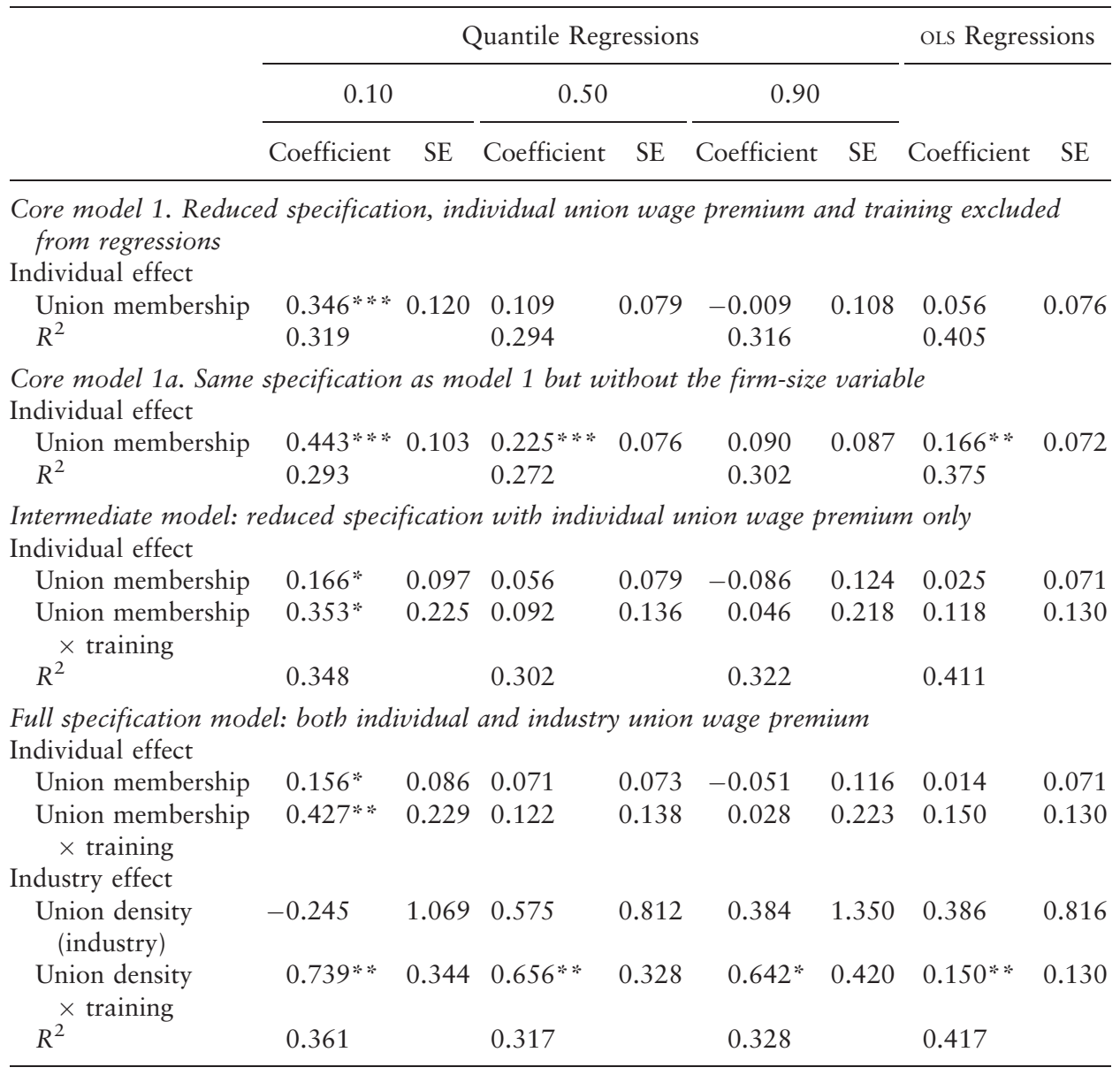

"Significant at the 10 percent level.

* Significant at the 5 percent level.

**:Significant at the 1 percent level.

Note: Number of observations $=683 . R^{2}$ is pseudo- $R^{2}$ for quantile regressions and standard $R^{2}$ for oLs regressions. The SEs are bootstrapped using 200 replications, running a clustered bootstrap (where the clusters are the firms) with the quantile regression run within each draw.

Source: Authors' calculations based on data from Regional Program on Enterprise Development for Ghana (Wave III 1994).

worker is trained, the degree of unionization in the industry affects individual wages positively, hinting at unions' bargaining power in extracting some of the rents from training from the firm and sharing it with members. ${ }^{17}$ This effect

17. For unions to bring about higher wages, there must first be some surplus arising from the employment relationship, and the union must have sufficient bargaining power to induce the firm to share this surplus in the form of higher wages. It should be noted that unions can also sometimes increase or decrease this surplus. 
persists at the higher end of the wage distribution as well. The union wage premium associated with individual union membership decreases slightly when the industry union density variables are included, hinting at their importance in modeling the union wage premium in Ghana.

The oLs results are strikingly different from the quantile regression results. The ols estimates indicate the presence of only an indirect aggregate union premium and no direct premium from individual union membership for all three main models (see table 2). These findings substantiate the importance of the quantile regression approach as an alternative or a complement to the more traditional oLs-based analysis.

Our findings correspond to those of Chamberlain (1994) but are even more pronounced. Chamberlain reports a mean union premium (oLs estimate) of 15.8 percent for U.S. manufacturing firms, with a 28.0 percent premium at the bottom decile of the wage distribution and a 0.3 percent premium at the top decile, implying that the mean union wage premium is driven primarily by the bottom decile of the conditional distribution. In the ols regression here, the union premium vanishes altogether. The quantile regression reveals that this happens because only the bottom decile of the conditional distribution receives a union wage premium.

Schultz and Mwabu (1998) also find distinct asymmetries across the conditional distribution of South African wages. Again, however, the results for Ghana are even more pronounced. In addition to the union wage premium for the bottom decile, Schultz and Mwabu find a statistically significant union wage premium at the top decile of the conditional distribution (11 percent for Africans and -24 percent for whites), as well as a statistically significant and positive union premium of 60 percent for the ols regressions (for Africans only), which this study does not. The data in the Shultz and Mwabu study, however, do not allow controlling for firm size, which may be an important determinant of union placement. Excluding firm size from the core model of this study (model $1 \mathrm{a}$ in table 2 ) yields a statistically significant union wage premium at the median and increases the individual union premium to almost 56 percent $(\exp [0.443]-1)$. Doing so also yields a statistically significant union premium for the ols regression. Although this may help explain the discrepancies between the Schultz and Mwabu results and the present results, that is not to say that the two sets of results would necessarily have been similar had Schultz and Mwabu had firm-size data in their South Africa dataset. Rather, the main point is that the union premium may be substantial even after controlling for firm size, as our results indicate.

Even if firm size is included as an explanatory variable, concerns remain about the possible selection of workers into unions at the individual level based on unobservables (ability, motivation). Because union and nonunion workers have different observable characteristics (see table 1), they might well have different unobservable characteristics (ability, motivation) as well. Again, that implies that the results here are more suggestive than explicitly causal. 


\section{Conclusion}

This study establishes important associations between wages and individual union membership and union density at the industry level of manufacturing workers in Ghana. Findings of distinct asymmetries in the association of union membership and wages across the conditional wage distribution of workers in Ghanaian manufacturing are consistent with the expectation that unions bargain mainly on behalf of workers at the lower end of the wage distribution. The analysis finds evidence of a union premium related to individual union membership and an additional individual union premium coming through training, interpretable as unions promoting training or bargaining and sharing with members some of the rents obtained by firms. An additional spillover effect to trained nonunion and union workers comes through the degree of unionization of the industry interacted with training.

OLS, the workhorse in this line of inquiry, yields strikingly different results: The union wage premium disappears. This highlights the importance of quantile regression techniques, especially where there is a presumption that the impacts may differ across the conditional distribution of the dependent variable. Although this study captures parts of the nonrandom placement of unions at the aggregate level by including firm size, concerns related to the possible selection of workers into unions based on unobservable characteristics of individuals (ability, motivation) remain.

Further research is required to shed additional light on several issues. Is there a causal relationship, or is the observed positive association between wages and union membership and union density at the industry level due simply to a nonrandom placement of unions? Do unions generate the rents that are subsequently awarded to union members through increased wages by reducing turnover and wage negotiation cost and increasing productivity, or do they merely act as the voice of the union members, extracting already existing rents from firms through their bargaining power, rents that the workers could not obtain on their own? Although suggestive, the data limitations of this study do not allow for explicit causal answers to these questions. Some evidence suggests that union workers are more productive than their nonunion colleagues in manufacturing in general (Sapsford and Tzannatos 1993). This appears to be a potentially fruitful avenue for further research in Ghana.

However, all such efforts are severely handicapped by the lack of data. Data needs should be considered in the design of future surveys aimed at collecting matched employer-employee data sets. Getting at the dual causality with respect to union placement into certain sectors or industries is data intensive as well. Drawing causal conclusions on the impact of unions on wages (and productivity, if data were also available) requires panel data on workers and possibly on firms to allow extracting worker-, firm-, sector-, or industry-specific effects. 
Appendix: Regression Variables and Sample Mean Characteristics

\section{Table A-1. Regression Variables and Their Definitions}

\begin{tabular}{|c|c|}
\hline Variable & Definition \\
\hline Log(wages) & Log of monthly wages of individual \\
\hline \multicolumn{2}{|l|}{ Individual variables } \\
\hline Age & Age of individual \\
\hline Age squared & Age of individual squared \\
\hline Gender dummy variable & 1 if a woman, 0 otherwise \\
\hline \multicolumn{2}{|l|}{ Education } \\
\hline \multicolumn{2}{|c|}{$\begin{array}{l}\text { Dummy variables for highest level of education completed ( } 1 \text { if as stated, } 0 \text { otherwise; } \\
\text { "no completed education" is the reference group) }\end{array}$} \\
\hline Primary & Primary education \\
\hline Middle & Middle education \\
\hline Secondary & Secondary school \\
\hline Vocational & Vocational education \\
\hline Polytechnic & Polytechnic or technical education \\
\hline Professional & Professional education \\
\hline University & University \\
\hline \multicolumn{2}{|l|}{ Occupation } \\
\hline \multicolumn{2}{|c|}{$\begin{array}{l}\text { Dummy variables for occupation ( } 1 \text { if as stated, } 0 \text { otherwise; "production worker" } \\
\text { is the reference group) }\end{array}$} \\
\hline Administration & Administrative staff \\
\hline Commercial & Commercial and sales staff \\
\hline Professional & Professional staff \\
\hline Support & Support staff \\
\hline Manager & Managerial staff \\
\hline Tenure (years) & Years of tenure in the firm \\
\hline Tenure squared & Years of tenure in the firm squared \\
\hline Training & 1 if trained in the firm, 0 otherwise \\
\hline Tenure $\times$ training & Interaction of tenure and training \\
\hline Permanent & 1 if permanent contract, 0 otherwise \\
\hline Permanent $\times$ training & Interaction of permanent and training \\
\hline Union membership & 1 if member of a union, 0 otherwise \\
\hline Union membership $\times$ training & Interaction of union membership and training \\
\hline \multicolumn{2}{|l|}{ Firm variables } \\
\hline Union density (industry) & $\begin{array}{l}\text { Share of the firms in an industry with at least } \\
1 \text { unionized worker }\end{array}$ \\
\hline Union density $\times$ training & Interaction of union density and training \\
\hline $\log ($ firm size $)$ & Log of the number of firm employees \\
\hline Accra & 1 if firm is in Accra, 0 otherwise \\
\hline
\end{tabular}

Note: The reduced core model excludes "training" and "union density" and their interaction terms, the intermediate model excludes "union density" and their interactions terms, and the full model includes all the variables.

Source: Authors' model. 
Table A-2. Sample Mean Characteristics

\begin{tabular}{|c|c|c|}
\hline Variable & Mean & $\mathrm{SD}$ \\
\hline Log(wages) & 10.590 & 0.062 \\
\hline Age & 34.7 & 0.700 \\
\hline Age squared & 1331.0 & 53.176 \\
\hline Gender & 0.189 & 0.025 \\
\hline \multicolumn{3}{|l|}{ Individual characteristics } \\
\hline \multicolumn{3}{|l|}{ Education } \\
\hline None & 0.094 & 0.018 \\
\hline Primary & 0.031 & 0.009 \\
\hline Middle & 0.490 & 0.026 \\
\hline Secondary & 0.123 & 0.019 \\
\hline Vocational & 0.126 & 0.016 \\
\hline Polytechnic & 0.088 & 0.016 \\
\hline Professional & 0.034 & 0.009 \\
\hline University & 0.015 & 0.005 \\
\hline \multicolumn{3}{|l|}{ Occupation } \\
\hline Production worker & 0.423 & 0.031 \\
\hline Administration & 0.130 & 0.020 \\
\hline Commercial & 0.067 & 0.012 \\
\hline Professional & 0.040 & 0.009 \\
\hline Support & 0.122 & 0.025 \\
\hline Manager & 0.119 & 0.015 \\
\hline Tenure (years) & 6.6 & 0.504 \\
\hline Tenure squared & 87.8 & 12.926 \\
\hline Training & 0.309 & 0.036 \\
\hline Tenure training & 2.012 & 0.279 \\
\hline Permanent & 0.978 & 0.009 \\
\hline Permanent $\times$ training & 0.300 & 0.035 \\
\hline Union membership & 0.296 & 0.039 \\
\hline Union membership $\times$ training & 0.083 & 0.019 \\
\hline \multicolumn{3}{|l|}{ Firm characteristics } \\
\hline $\log$ (number of employees) & 3.735 & 0.119 \\
\hline Union density $\times$ industry & 0.289 & 0.005 \\
\hline Union density $\times$ training & 0.198 & 0.012 \\
\hline Accra & 0.616 & 0.052 \\
\hline
\end{tabular}

Notes: The sample consists of 683 workers. The clustering of workers within firms has been taken into account in the calculation of SDs.

Source: Authors' calculations based on data from Regional Program on Enterprise Development for Ghana (Wave III 1994).

\section{REFERENCES}

Becker, Gary S. 1964. Human Capital. Chicago: Chicago University Press.

Booth, Alison L. 1995. The Economics of the Trade Union. Cambridge: Cambridge University Press.

Booth, Alison L., and Monojit Chatterji. 1998. "Unions and Efficient Training." Economic Journal 108(447):328-43.

Booth, Alison L., Marco Francesconi, and Gylfi Zoega. 1999. "Training, Rent-sharing and Unions." Discussion Paper 2200. Centre for Economic Policy Research, London. 
Card, David. 1996. "The Effect of Unions on the Structure of Wages: A Longitudinal Analysis." Econometrica 64(4):957-79.

Chamberlain, Gary. 1994. “Quantile Regression, Censoring and the Structure of Wages.” In Advances in Econometrics, ed. Christopher Sims. New York: Elsevier.

Chaykowski, Richard P., and George A. Slotsve. 2002. "Earnings Inequality and Unions in Canada." British Journal of Industrial Relations 40(3):493-519.

Freeman, R. 1980. "Unionism and the Dispersion of Wages." Industrial and Labor Relations Review 34(1):3-23.

Freeman, Richard B., and James L. Medoff. 1984. What Do Unions Do? New York: Basic Books.

Gould, W. W. 1992. "sg11.1: Quantile Regression with Bootstrapped Standard Errors.” Stata Technical Bulletin 9:19-21. Reprinted in Stata Technical Bulletin Reprints 2:137-39.

1997. "sg70: Interquantile and Simultaneous-Quantile Regression.” Stata Technical Bulletin 38:14-22. Reprinted in Stata Technical Bulletin Reprints 7:167-76.

Gray, Paul S. 1981. Unions and Leaders in Ghana: A Model of Labor and Development. New York: Conch Magazine Limited.

Koenker, R., and G. Basset Jr. 1978. "Regression Quantiles.” Econometrica 46(1):33-50.

—. 1982. "Robust Tests for Heteroscedasticity Based on Regression Quantiles." Econometrica $50(1): 43-61$.

Kristensen, N., and D. Verner. 1999. "Labor Market Distortions in Côte d'Ivoire: A Quantile Regression Analysis of Employer-Employee Data.” Africa Regional Labor Market Study, World Bank, Washington, D.C.

Lewis, H. Gregg. 1963. Unionism and Relative Wages in the United States. Chicago: Chicago University Press.

-1986. Union Relative Wage Effects: A Survey. Chicago: Chicago University Press.

Maloney, W. F., and E. P. Ribeiro. 1999. "Efficiency Wage and Union Effects in Labor Demand and Wage Structure in Mexico: An Application of Quantile Analysis.” Policy Research Working Paper 2131. World Bank, Washington, D.C.

Mincer, Jacob. 1974. Schooling, Experience, and Earnings. New York: Columbia University Press.

Panagides, Alexis, and Harry Anthony Patrinos. 1994. "Union-Nonunion Wage Differentials in the Developing World: A Case Study of Mexico.” Policy Research Working Paper 1269. World Bank, Washington, D.C.

Pencavel, J. 1995. "The Role of Labor Unions in Fostering Economic Development.” Policy Research Working Paper 1469. World Bank, Washington, D.C.

Psacharopoulos, George. 1985. "Returns to Education: A Further International Update and Implications." Journal of Human Resources 20(4):583-97.

—. 1994. "Returns to Education: A Global Update.” World Development 22(9):1325-343.

Rama, Martin. 2000. "Wage Misalignment in CFA Countries: Were Labour Market Policies to Blame?” Journal of African Economies 9(4):475-511.

Rogers, W. H. 1992. “sg11: Quantile Regression Standard Errors.” Stata Technical Bulletin 9:16-19. Reprinted in Stata Technical Bulletin Reprints 2:133-37.

Sapsford, David, and Zafiris Tzannatos. 1993. The Economics of the Labor Market. London: Macmillan.

Schaffner, J. A. 1998. "Premiums to Employment in Larger Establishments: Evidence from Peru." Journal of Development Economics 55:81-113.

Schultz, T. Paul, and Germano Mwabu. 1998. "Labor Unions and the Distribution of Wages and Employment in South Africa." Industrial and Labor Relations Review 51(4):680-703.

Standing, G. 1992. "Do Unions Impede or Accelerate Structural Adjustment? Industrial versus Company Unions in an Industrialising Labour Market." Cambridge Journal of Economics 16:327-54.

Velenchik, A. D. 1997. “Government Intervention, Efficiency Wages, and the Employer Size Wage Effect in Zimbabwe." Journal of Development Economics 53:305-38. 